\title{
David Stark, 2009, The sense of dissonance. Accounts of worth in economic life, Princeton and Oxford: Princeton University Press
}

\author{
Koen Frenken
}

Published online: 15 November 2011

(C) The Author(s) 2011. This article is published with open access at Springerlink.com

At first glance, economic sociologists and evolutionary economists should have a lot to offer to each other. Both departed from mainstream economics embracing bounded rationality, heterogeneity of firms, endogenous preferences, imperfect markets, and last but not least institutions. Nevertheless, intellectual exchange between the two fields has been rare, and mostly concentrated on the specific sub-field of organizational ecology (as it is called in economic sociology) viz. industrial dynamics (as it is known in evolutionary economics). After reading the book by Stark, I understood better why these fields have seen so little crossovers.

As Stark explains at length in chapter 1 and chapter 5, economic sociologists have carefully avoided the explananda of mainstream economists hereby creating a stable mode of peaceful co-existence. In particular, while economic sociologists would emphasize the role of social values in economic behavior and institutions, they left the explanation of value as expressed in prices and profits entirely to economists. Evolutionary economists choose an opposite route. From its start (Nelson and Winter 1982), its ambitious aim was to change mainstream economic theory altogether by providing an alternative theory based on different assumptions and mechanisms, particularly in the fields of the theory of the firm, industrial organization and economic growth.

A growing number of economic sociologists argue that their discipline should no longer shy away from questions of economic value. In doing so,

K. Frenken $(\bowtie)$

School of Innovation Sciences, Eindhoven University of Technology,

Eindhoven, The Netherlands

e-mail:k.frenken@tue.nl 
economic sociology and evolutionary economics will have much more to learn from one another. Stark's book is definitely the best example to date of this fruitful encounter. In his work on innovative companies in various industry contexts (engineering, new media, finance), his starting point is to analyze the firm as an organization where different logics of values ('orders of worth') operate, with the logic of price and profit being one out of many. One of the most important messages of the book holds that variety in values is not necessarily a source of conflict, as it was traditionally assumed in economic sociology. If the various 'orders of worth' are well managed within a firm, it will be a great source of innovation as well as of adaptability. Different values generate different cognitive orientations and from this cognitive variety innovations can stem through "recombinant innovation" (van den Bergh 2008). Stark's thesis is well illustrated by three very different case studies in chapter 2 to 4: A Hungarian factory operating in planning and market modes at the same time, new media start-ups in during the dot.com boom and a Wall Street trading room before and after 11 September 2001.

The book by Stark is not just interesting because it provides a new theory of corporate innovation. Equally important is that it breaks down the standard view that the firms solely operate in a single "economic sphere" and, hence, their life course is driven by a single selection criterion. Rather, firms operate in many institutional spheres at the same time, with employees oriented towards each of these spheres to different degrees. One can still maintain the classical sociological view that modern societies are functionally differentiated in sub systems at the macro-level (science, politics, markets, art, et cetera) each with its own dominant selection criterion (truth, power, profit, beauty, et cetera). However, to infer from this that organizations operate in single sub-systems, then, is a "macro-to-micro" fallacy that is untenable.

For the field of evolutionary economics, Stark's book raises a number of new questions. First, how do we model organizations subject to multiple selection criteria at the same time? A recent model based on NK landscapes seems promising in this respect (Ethiraj and Levinthal 2009). Second, does our genetic notion of recombination as a source of technological innovation really capture the recombinant process between employees oriented towards different values? Finally, should we abandon the notion of strict institutional spheres, for example, in our study of university-industry-government relations? It would mean that we shift our focus from university-industrygovernment collaboration to the study of how a single organization operates in the three spheres at the same time.

Needless to say, I recommend all fellow evolutionary economists to read this book and reflect on the lessons that can be learned for evolutionary theorizing in economics, and in the social sciences more generally. 
Open Access This article is distributed under the terms of the Creative Commons Attribution Noncommercial License which permits any noncommercial use, distribution, and reproduction in any medium, provided the original author(s) and source are credited.

\section{References}

Ethiraj S, Levinthal DA (2009) Hoping for A to Z while rewarding only A: complex organizations and multiplegoals. Organ Sci 20:4-24

Nelson RR, Winter SG (1982) An evolutionary theory of economic change. Belknap Press, Cambridge

van den Bergh JCJM (2008) Optimal diversity: increasing returns versus recombinant innovation. J Econ Behav Organ 68(3-4):565-580 